\title{
CIÊNCIANATURA
}

\section{Effect of Genetic Material and Rotation on the Properties of Charcoal}

João Paulo Romanelli*, Maria Carolina Pereira Gonçalves, Mayara Franco Costa

e Ana Márcia Macedo Ladeira Carvalho

Universidade Federal de Viçosa, MG, Brasil

\begin{abstract}
This study aimed to evaluate chemical properties and yield of charcoal from two Eucalyptus urophylla clones considering the first and second rotation of the wood. The study was carried out with material from Arcelor Mittal Jequitinhonha, with a mean age of 61.5 months. The values of fixed carbon, volatile materials, ash content, higher calorific value, gravimetric yield, liquid yield and gas yield were determined. The data were analyzed statistically by Analysis of Variance (ANOVA) and significant differences were compared by the Tukey test ( $p<0.05)$. The results showed significant differences for the fixed carbon contents (67\% and $70.5 \%)$ and volatile materials $(32 \%$ and 29\%) of clones AEC 0182 and AEC 0296, respectively. The analysis of the results showed that both the first and second rotation woods have satisfactory characteristics for charcoal production and are not influenced by the effect of the rotations.
\end{abstract}

Keywords: Carbonization; Charcoal yield; Chemical properties; Eucalyptus urophylla 


\section{Introduction}

Discussions on global climate change have encouraged participation of renewable energy sources in the energy matrix of countries in recent years (THE WORLD BANK, 2010). Since the entry into force of the Kyoto Protocol, Clean Development Mechanism (CDM) projects have grown significantly for the purpose of encouraging sustainable energy production and reducing greenhouse gas emissions (IPCC, 2014). In Brazil, the renewable energy matrix represents about $41.2 \%$ of the domestic supply and $8.2 \%$ of this total corresponds to sources such as firewood and charcoal (EPE, 2015).

The extensive Brazilian forest area, associated to favorable edaphoclimatic conditions, confers innumerable competitive advantages for the development of silviculture in the country (XAVIER AND SILVA, 2010; STUEPP et al., 2017), with most commercial plantations being conducted with different species of eucalyptus and pinus (HEIMANN et al., 2015). Forest biomass from reforestation is used in several industrial segments, mainly in the production of cellulose, charcoal and reconstituted panels, also supplying the construction and furniture manufacturing sectors (VALLE et al., 2013). In Brazil, commercial eucalyptus plantations are mostly used for the production of charcoal to supply the demand of the steel and metallurgical industry (ABRACAVE, 2001, ABRAF, 2012). In the world context, the country stands out as the largest producer of charcoal (IEA, 2011) with large-scale industrial application (AMS, 2009, MMA, 2011, ABRAF, 2012).

Charcoal is highly variable in terms of quality, being influenced by several factors, such as management practices, age, plantation sites (VALLE et al., 2010, SANTOS et al., 2012, PROTÁSIO et al., 2012), the size of the materials subjected to carbonization, the wood used as raw material and the production system itself (SARAVANAKUMAR et al., 2006; BUSTAMANTE et al., 2013; CARNEIRO et al., 2016). The homogeneity of the produced charcoal, in turn, is fundamental in the process of production of steel and pig iron of good quality (PEREIRA et al., 2000; PROTASIO et al., 2014). In this way, it is necessary to know the characteristics of the wood, the process of production of the charcoal, as well as the correlation between these factors (PEREIRA et al., 2000, CARNEIRO et al., 2016).

The increasing demand for wood has led to the development of research aimed at increasing plant productivity and reducing the cutting cycle (CARNEIRO et al., 2016). Particularly for the energy sector, short-rotation forests come as alternatives to obtain wood at reduced intervals and lower production costs (ELOY et al., 2015). However, the properties of the wood are influenced by the cutting cycle, and therefore by the age of the forests (OLIVEIRA et al., 2010; CARNEIRO et al., 2016).

Consequently, the establishment of commercial plantations for the production of charcoal involves the selection of superior genetic material and the adoption of appropriate silvicultural techniques, reconciling the productivity of the plantations with the desired quality of the wood for energy purposes (IPEF, 2010; OLIVEIRA et al., 2010). The objective of the present study was to evaluate the yield and the properties of the charcoal produced from the first and second rotation wood with cutting cycles of approximately 61.5 months considering two different genetic materials of Eucalyptus urophylla S.T. Blake from commercial plantations located in the state of Minas Gerais.

\section{Material and methods}

The research was carried out with materials from commercial plantations of Eucalyptus urophylla S. T. Blake located in Itamarandiba, state of Minas Gerais, Brazil, from Arcelor Mittal Jequitinhonha Company. Two hybrids of Eucalyptus urophylla S. T. Blake (clone AEC 0182 and clone AEC 0296), submitted to the same cultural treatments (fertilization, ant control and weed competition) were analyzed.

The local landform is characterized as Highland and the predominant type of soil is the Red-Yellow Latosol. The average annual temperature is $20.76^{\circ} \mathrm{C}$, with maximum and minimum averages of $25.8^{\circ} \mathrm{C}$ and $15.7^{\circ} \mathrm{C}$, respectively (local data of twenty years). The average relative humidity of the air is about $68.43 \%$ and the average annual precipitation is about $1,156,75 \mathrm{~mm}$, with water deficit between the months of May to September. The identification and characteristics of the used material in this study are presented in Table 1.

Four trees of each genetic material and rotation were used, totaling 16 trees. Each tree was sectioned into threemeter logs, and the basal portion of each new section $(30 \mathrm{~cm})$ was used to compose the composite sample of each tree (Figure 1). After the bark was removed, the material was transferred to the Wood Properties Laboratory of the Federal University of Viçosa. 
Table 1 - Data of the studied material

\begin{tabular}{c|c|c|c|c|c|c}
\hline $\begin{array}{c}\text { Genetic } \\
\text { material }\end{array}$ & Rotation & Age (months) & Altitude (m) & Latitude (UTM) & Longitude (UTM) & Spacing (m) \\
\hline \multirow{2}{*}{ AEC 0182 } & First & 63 & 1001 & 8041803 & 741306 & 3,00 X 2,80 \\
& Second & 62 & 929 & 8033001 & 720372 & 3,00 X 2,00 \\
\hline \multirow{2}{*}{ AEC 0296 } & First & 60 & 926 & 8037277 & 740590 & $3,00 \times 2,80$ \\
& Second & 61 & 937 & 8033019 & 720908 & 3,00 X 2,00 \\
\hline
\end{tabular}

Source - Valle et al, 2013

Figure 1 - Schematic of withdrawal of test specimens

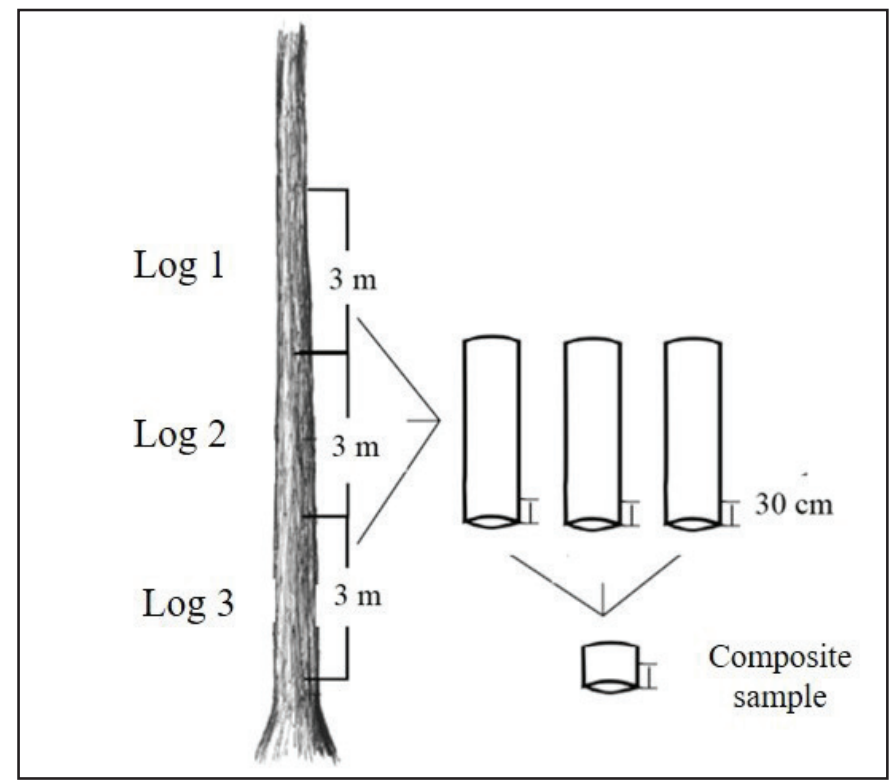

Source - Valle et al., 2013

\subsection{Carbonization process}

The laboratory carbonization was performed after the conversion of the specimens into wedges, which were weighed and transferred to an adapted metal container. After this step the material was taken to the muffle. The carbonization step was started with the temperature of $150{ }^{\circ} \mathrm{C}$ and finished at $450{ }^{\circ} \mathrm{C}$. The heating control was conducted manually, resulting in a heating rate of $1.36{ }^{\circ} \mathrm{C} \cdot \mathrm{min}^{-1}$. Table 2 shows the details of the carbonization step employed.

Table 2 - Temperature and time of carbonization as a function of the carbonization rate.

\begin{tabular}{c|c|c|c|c|c|c}
\hline \multirow{2}{*}{ Step } & \multicolumn{4}{|c|}{ Temperature $\left({ }^{\circ} \mathrm{C}\right)$} & \multicolumn{2}{c}{ Heating rate $\left({ }^{\circ} \mathrm{C} / \mathrm{min}\right)$} \\
\cline { 2 - 6 } & 150 & 200 & 250 & 350 & 450 & 1,36 \\
\hline Time & 1 hour & 1 hour & $1 \mathrm{~h} 30$ & $1 \mathrm{~h} 30$ & $30 \mathrm{~min}$ & Total time $5 \mathrm{~h} 30 \mathrm{~m}$ \\
\hline
\end{tabular}

During the carbonization the condensed products were collected and the gases were discarded. At the end of each carbonization, the adapted container was removed from the muffle and left to cool to room temperature for subsequent weighing of the charcoal and condensed products. At the end of this phase, the gravimetric yield of the charcoal was determined in relation to the dry mass of wood, gases yield and liquids yield.

\subsection{Chemical properties of charcoal}

The higher calorific value (H.C.V) was determined using an adiabatic calorimetric pump, according to ABNT NBR 8633 (1983). The procedures used for the immediate chemical analysis were based on the ABNT NBR 8112 (1983) standard for determination of volatile matter content, ash content and fixed carbon content on dry basis.

In the preparation stage of the material, the charcoal was milled, sieved and subsequently weighed. The carbon retained in the 40 and 60 mesh sieves was oven dried at $103{ }^{\circ} \mathrm{C}$ and used in the determination of the parameters. 


\subsection{Statistical analysis}

The data were analyzed according to a $2 \times 2$ factorial design (two genetic materials and two rotations), with four replicates of each genetic material and rotation, totaling 12 composite sample units (carbonizations). The results were submitted to analysis of variance (ANOVA) and, when significant differences were established, the treatments were compared by the Tukey test at 5\% of significance. Statistical analyses were performed by the software Statistica ${ }^{\circledR} 7.0$.

\section{Results and discussion}

Table 3 presents the results of the analysis of variance (ANOVA) for the chemical properties and charcoal yield of Eucalyptus urophylla S. T Blake from first and second rotation after carbonization in muffle.

Table 3 - Variance analysis for the contents of volatile materials, fixed carbon, ash content, higher calorific value, gravimetric yield, liquids yield and gases yield.

\begin{tabular}{|c|c|c|c|c|c|c|c|c|}
\hline \multicolumn{9}{|c|}{ ANOVA } \\
\hline $\mathrm{FV}$ & D.F & V.M (\%) & F.C (\%) & A.C $(\%)$ & H.C.V $(\%)$ & G.Y (\%) & L.Y (\%) & R. G $(\%)$ \\
\hline Genetic Material & 1 & $43,38^{*}$ & $46,04^{*}$ & $0,03945 \mathrm{~ns}$ & $365098 \mathrm{~ns}$ & $1,57 \mathrm{~ns}$ & $1,36 \mathrm{~ns}$ & $0,01 \mathrm{~ns}$ \\
\hline Rotation & 1 & $15,58 \mathrm{~ns}$ & $14,79 \mathrm{~ns}$ & $0,01039 \mathrm{~ns}$ & $66085 \mathrm{~ns}$ & $0,22 \mathrm{~ns}$ & $21,93 \mathrm{~ns}$ & $17,75 \mathrm{~ns}$ \\
\hline $\begin{array}{c}\text { Genetic Material } \\
\text { vs Rotation }\end{array}$ & 1 & $1,19 \mathrm{~ns}$ & $1,07 \mathrm{~ns}$ & $0,00299 \mathrm{~ns}$ & $62 \mathrm{~ns}$ & $4,36 \mathrm{~ns}$ & $4,07 \mathrm{~ns}$ & $16,85 \mathrm{~ns}$ \\
\hline Total & 15 & - & - & - & - & - & - & - \\
\hline
\end{tabular}

That is: FV: variation factor; vs: versus; DF: degrees of freedom; V.M: Volatile materials; F.C: Fixed carbon; A.C: Ash content; H.C.V: Higher calorific value; G.Y: Gravimetric Yield; L.Y: Liquid yield; G.Y: Gas yield; *: significant at 5\% probability by Tukey's test; ns: not significant at 5\% probability by the Tukey test.

It is observed that, in general, significant differences were found for the effect of different genetic materials under the charcoal quality. However, the effect of the different rotations did not significantly influence the properties and yield of the produced charcoal. Table 4 shows the mean values and standard deviation of charcoal properties and yields determined in this study.

Table 4 - Mean values and standard deviation of charcoal properties as a function of genetic material and wood rotations

\begin{tabular}{c|c|c|c}
\hline \multirow{2}{*}{ V.F. (\%) } & \multicolumn{2}{|c|}{ Clone AEC 0182 } & \multicolumn{2}{c}{ Clone AEC 0296 } \\
\cline { 2 - 4 } & First rotation & Second rotation & First rotation \\
\hline V.M & $67,3 \pm 1,87$ & $66,8 \pm 2,06$ & $70,8 \pm 0,98$ \\
\hline F.C & $30,2 \pm 3,91$ & $29,8 \pm 2,98$ & $0,450 \pm 0,160$ \\
\hline A.C & $0,519 \pm 0,057$ & $0,500 \pm 0,008$ & $27,8 \pm 3,91$ \\
\hline H.C.V & $6848,32 \pm 155,20$ & $6980,8 \pm 299,75$ & $7154,38 \pm 157,16$ \\
\hline G.Y & $31,13 \pm 0,970$ & $30,32 \pm 2,390$ & $30,71 \pm 1,400$ \\
\hline L.Y & $43,271 \pm 3,109$ & $39,921 \pm 4,479$ & $7278,97 \pm 312,14$ \\
\hline G.Y & $25,6 \pm 3,610$ & $29,76 \pm 6,530$ & $41,679 \pm 3,063$ \\
\hline
\end{tabular}

That is: V.F: Variation Factor (\%); V.M: Volatile Materials; F.C: Fixed Carbon; A.C: Ash Content; H.C.V: Higher Calorific Value; G.V: Gravimetric Yield; L.Y: Liquid Yield; G.Y: Gas Yield. 


\subsection{Fixed Carbon and Volatile Materials}

Significant statistic differences were found for the fixed carbon content and volatile matter content, considering the different clones studied. The general average found for the fixed carbon content was $68.93 \%$, and for the content of volatile materials values between $22 \%$ and $35 \%$ were found, with a general average of $30.3 \%$. Similar values are reported in the literature by Neves et al. (2011), Protásio et al. (2013) and Reis et al. (2012), varying from $73 \%$ to $80 \%$ for the fixed carbon content, and from $19 \%$ to $26 \%$ for the content of volatile materials. Costa et al. (2014), analyzing the charcoal produced from coffee wood, reported values for fixed carbon content and volatile materials around $69.93 \%$ and $28.5 \%$, respectively.

The results can be explained by the trend of the inversely proportional relationship between the fixed carbon content and the volatile matter content of charcoal. However, for Arantes et al. (2013) this relation is not valid when considering different classes of wood diameter. According to Botrel et al. (2007), the contents of fixed carbon and volatile materials are strongly influenced by the temperature and heating rate of the system. For the purpose of this study, such factors were constant for all treatments.

\subsection{Ash Content and Higher Calorific Value}

According to Reis et al. (2012), there is an inversely proportional relationship between the ash content and the calorific value of charcoal. Ashes do not contribute to the combustion of charcoal; therefore higher ash contents tend to decrease the calorific value of the produced charcoal. In this study, no significant differences were found for the ash content by observing the different rotations and the genetic material, obtaining an average value of $0.46 \%$.

In the literature, values ranging from 0.16 to $2 \%$ for the ash content of charcoal from Eucalyptus spp clones are reported (TRUGILHO et al., 2005; NEVES et al., 2011; ASSIS et al., 2012; REIS et al. al., 2012), consequently the values found are consistent with the results of other studies, which may show that there was no contamination of wood and charcoal during carbonization. Valle et al. (2011) mentioned that ash content above 7\% is considered high, and Barcellos et al. (2005) pointed out that charcoal for steel use must have a low ash content, since this fraction of charcoal can decrease the quality of the steel and the metal alloys produced. In the study by Protásio et al. (2014) the charcoal properties of four clones of Eucalyptus spp. at the ages of 57 and 69 months showed significant differences for the ash content considering the effect of the age of the plantation, having observed the decrease of the contents with the increase of the age. This behavior was not observed in this research. The lowest amount of ash content was found for clone AEC 0296 at the age of 60 to 61 months.

No significant differences were obtained for the superior calorific value (SCV) considering the different genetic materials and the rotations. The highest SCV value was for the second rotation clone AEC $0296\left(7278.97 \mathrm{Kcal}_{\mathrm{kg}}{ }^{-1}\right)$. The overall average found for the clones of Eucalyptus urophylla S. T Blake was $7065.62 \mathrm{Kcal}_{\mathrm{kg}}{ }^{-1}$. Similar SCV values were reported by Dias Júnior et al. (2015) evaluating the charcoal of seven genetic materials of Eucalyptus spp at seven years of age, ranging from $6,917 \mathrm{kcal} . \mathrm{kg}^{-1}$ to $7,554 \mathrm{kcal} . \mathrm{kg}^{-1}$.

\subsection{Gravimetric Yield}

No significant differences were found for the gravimetric yield considering the different genetic materials and the rotations. The results ranged from $26.364 \%$ to $32.623 \%$, with an overall mean of $31.04 \%$. Trugilho et al. (2001), analyzing Eucalyptus grandis clones and applying similar carbonization steps used in this study (heating rate and final carbonization temperature), has reported values of gravimetric yield between 33.0 and $39.0 \%$, higher than those reported by this search. Arantes et al. (2013) analyzed the effect of wood diameter on the gravimetric yield has reported an average value of $34.2 \%$ for wood of $14.2 \mathrm{~cm}$ and $33 \%$ for the class of $8.1 \mathrm{~cm}$, with an overall mean of $33,8 \%$. Similar values to those found in the present study were reported by Botrel et al. (2007) studying Eucalyptus urophylla clones, with an overall mean of 35.03\%.

\subsection{Liquids and Gases yield}

No significant differences were found for the liquid yield considering both the effect of the genetic material and the effect of the different rotations. Data obtained ranged from $32.94 \%$ to $47.07 \%$, with the overall mean being $41.304 \%$. Values lower than those found in this study were reported by Trugilho et al. (2001), analyzing clones of Eucalyptus grandis, which varied from $19.2 \%$ to $22.6 \%$. Results similar to those obtained in the present study were presented by Leite et al. 
(2015) when studying the charcoal of coffee wood, considering different species and cultivation systems, obtaining a general average of $44.24 \%$.

No significant differences were found for the yield of non-condensable gases yield considering both the effect of the genetic material and the effect of the rotations. Values ranged from $20.28 \%$ to $29.67 \%$, with the overall mean of $27.65 \%$. Trugilho et al. (2001) found condensable gas yield data ranging from $39.0 \%$ to $46.0 \%$ for wood from Eucalyptus grandis clones, and Leite et al. (2015) reported values varying from $22.32 \%$ to $24.97 \%$ by charcoal from the coffee wood.

\section{Conclusions}

The wood of Eucalyptus urophylla S. T. Blake presented satisfactory characteristics for the production of charcoal, when evaluating the different rotations of the wood and the two genetic materials. The yield and chemical properties of the charcoal were not influenced by the effect of the rotations, however, the different genetic materials analyzed (clones AEC 0182 and AEC 0296) presented significant differences for the content of volatile materials and fixed carbon. Therefore, the planting of the hybrid that provides the best raw material for the production of charcoal should be prioritized.

Based on the results, it was possible to show the advantage of minimizing the environmental impacts that the management of the plantations results when compared to the reforestation, considering that the characteristics of the charcoal do not differ between the first and the second rotation of the wood.

\section{References}

ARANTES MDC, TRUGILHO PF, SILVA JRM, ANDRADE CR. Características do carvão de um clone de Eucalyptus grandis W. Hill ex Maiden x Eucalyptus urophylla STB. Cerne, 2013:19(3): 423-431.

ASSIS MR, PROTÁSIO TP, ASSIS CO, TRUGILHO PF, SANTANA WMS. Qualidade e rendimentos do carvão vegetal de um clone híbrido de Eucalyptus grandis x Eucalyptus urophylla. Pesq. Flor. Bras., 2012:32(71): 291-302.

ASSOCIAÇÃO BRASILEIRA DE FLORESTAS RENOVÁVEIS. Anuário Estatístico de Consumo de Carvão Vegetal. Belo Horizonte (Brasil): 2001.

ASSOCIAÇÃO BRASILEIRA DE NORMAS TÉCNICAS. NBR 8112 - carvão vegetal - análise imediata. Rio de Janeiro (Brasil): Associação Brasileira De Normas Técnicas, 1983.

ASSOCIAÇÃO BRASILEIRA DE NORMAS TÉCNICAS. NBR 8633. Brasília (Brasil): Associação Brasileira De Normas Técnicas, 1983.

ASSOCIAÇÃO BRASILEIRA DE PRODUTORES DE FLORESTAS PLANTADAS. Anuário estatístico da ABRAF 2012. Brasília (Brasil): Associação Brasileira De Produtores De Florestas Plantadas, 2012.

ASSOCIAÇÃO MINEIRA DE SILVICULTURA. Números do setor. Belo Horizonte (Brasil): Associação Mineira De Silvicultura, 2009.

BARCELLOS DC, COUTO LC, MULLER MD, COUTO L. O estado da arte da qualidade da madeira de eucalipto para a produção de energia: um enfoque nos tratamentos silviculturais. Biomassa e Energia, 2005:22(1): 141-158.

BOTREL MCG, TRUGILHO PF, ROSADO SCS, SILVA JRM. Melhoramento genético das propriedades do carvão vegetal de Eucalyptus. Rev. Árvore, 2007:31(3): 391-398.

BUSTAMANTE-GARCÍA V, CARRILLO-PARRA A, GONZÁLEZ-RODRÍGUEZ H, RAMÍREZ-LOZANO RG, CORRAL-RIVAS JJ, GARZA-OCAÑAS F. Evaluation of a charcoal production process from Forest residues of Quercus sideroxy La Humb., \& Bonpl. in a Brazilian beehive kiln. Ind. Crops Prod., 2013;(42): 169-174.

CARNEIRO ACO, VITAL BR, FREDERICO PGU, FIALHO LF, FIGUEIRÓ CG, SILVA CMS. Efeito do material genético e do sítio na qualidade do carvão vegetal de madeira de curta rotação. Floresta, 2016:46(4): 473 - 480. 
COSTA TG, BIANCHI ML, PROTÁSIO TP, TRUGILHO PF, PEREIRA AJ. Qualidade da madeira de cinco espécies de ocorrência no cerrado para produção de carvão vegetal. Cerne, 2014:20(1): 37-46

DIAS JÚNIOR AF, ANDRADE AM, SOARES VW, COSTA JÚNIOR DS, FERREIRA DHAA, LELES PSS. Potencial energético de sete materiais genéticos de Eucalyptus cultivados no Estado do Rio de Janeiro. Sci. For., 2015:43(108): 833843.

ELOY E, CARON BO, DA SILVA DA, SOUZA VQ, TREVISAN R, BEHLING A et al. Produtividade energética de espécies florestais em plantios de curta rotação. Ciênc. Rural, 2015:45(8): 1424-1431.

EMPRESA DE PESQUISA ENERGÉTICA, Ministério de Minas e Energia. Balanço Energético Nacional. Rio de Janeiro (Brasil): Ministério de Minas e Energia, 2015, 281 p.

HEIMANN JP, DRESCH AR, ALMEIDA AN. Demanda dos estados unidos por carvão vegetal brasileiro. Sci. For., 2015: 25(2): 437-445.

INSTITUTO DE PESQUISAS E ESTUDOS FLORESTAIS [Internet]. Chave de Identificação de Espécies Florestais. [cited 2017 abr. 27]. Available from: http://www.ipef.br/identificacao/cief/.

INTERNATIONAL ENERGY AGENCY. Statistics \& Balances. Paris (França): International Energy Agency, 2011.

INTERGOVERNMENTAL PANEL ON CLIMATE CHANGE [Intermet]. Contribution of Working Group III to the Fifth Assessment Report of the Intergovernmental Panel on Climate Change. [cited 2014 abr. 11]. Available from: https://www.ipcc.ch/pdf/assessment-report/ar5/wg3/ipcc_wg3_ar5_full.pdf.

LEITE ERS, PROTÁSIO TP, ROSADO SCS, TRUGILHO PF, MELO ICN. Qualidade do carvão vegetal produzido a partir do cafeeiro para uso bioenergético. Coffee Sci., 2015:10(2): $251-261$.

MINISTÉRIO DO MEIO AMBIENTE. Plano de ação para prevenção e controle do desmatamento e das queimadas. Brasília (Brasil): Ministério Do Meio Ambiente, 2010, 200 p.

NEVES TA, PROTÁSIO TP, COUTO AM, TRUGILHO PF, SILVA VO, VIEIRA CMM. Avaliação de clones de Eucalyptus em diferentes locais visando à produção de carvão vegetal. Pesq. Flor. Bras., 2011:31(68): 319 - 330.

OLIVEIRA AC, CARNEIRO ACO, VITAL BR, ALMEIDA W, PEREIRA BLC, CARDOSO MT. Parâmetros de qualidade da madeira e do carvão vegetal de Eucalyptus pellita F. Muell. Sci. For., 2010:38(87): 431-439.

PEREIRA JCD, STURION JA, HIGA AR, HIGA RCV, SHIMIZU JY. Características da madeira de algumas espécies de eucalipto plantadas no Brasil. 38rd ed. Colombo: Embrapa Florestas; 2000.

PROTÁSIO TP, COUTO AM, REIS AA, TRUGILHO PF. Seleção de clones de Eucalyptus para a produção de carvão vegetal e bioenergia por meio de técnicas univariadas e multivariadas. Sci. For., 2013:42(97): 15-28.

PROTÁSIO TP, NEVES TA, REIS AA, TRUGILHO PF. Efeito da idade e clone na qualidade da madeira de Eucalyptus spp visando à produção de bioenergia. Sci. For., 2014:4(2): 465-477.

PROTÁSIO TP, TRUGILHO PF, NEVES TA, VIEIRA CMM. Análise de correlação canônica entre características da madeira e do carvão vegetal de Eucalyptus. Sci. For., 2012:40(95): 317-326.

REIS A.A., PROTÁSIO TP, MELO ICNA, TRUGILHO PF, CARNEIRO AC. Composição da madeira e do carvão vegetal de Eucalyptus urophylla em diferentes locais de plantio. Pesq. Flor. Bras., 2012:32(71): 277-290.

SANTOS SFOM, HATAKEYAMA K. Processo sustentável de produção de carvão vegetal quanto aos aspectos: ambiental, econômico, social e cultural. Prod., 2012:22(2): 309-321.

SARAVANAKUMAR A, HARIDASAN TM, KASTURI BR. Technical and feasibility study of conversion of long-stick wood to charcoal in a partial combustion metal kiln. Energy for Sustainable Development, 2006:10(3): 17-25.

STUEPP CA, WENDLING I, KOEHLER HS, ZUFFELLATO-RIBAS KC. Clonal forestry of piptocarphaangustifolia: survival and growth vigor in field conditions. Cerne, 2017:23(1): 69-74. 
YEPEZ-GARCÍA RA, OHNSON TM, ANDRÉS LA. Meeting the Electricity Supply: Demand Balance in Latin America \& the Caribbean. Washington (Estados Unidos): The World Bank, 2010.

TRUGILHO PF, LIMA JT, MORI FA, LINO AL. Avaliação de clones de Eucalyptus para a produção de carvão vegetal. Cerne, 2001:7(2): $104-114$

TRUGILHO PF, SILVA JRM, MORI FA, LIMA JT, MENDES LM, MENDES LFB. Rendimentos e características do carvão vegetal em função da posição radial de amostragem em clones de Eucalyptus. Cerne, 2005:11(2): 178-186.

VALLE AT, DIAS IS, SANTANA MAE. Relações entre propriedades químicas, físicas e energéticas da madeira de cinco espécies de cerrado. Sci. For., 2010:20(1): 137-145.

VALLE AT, MENDES RM, AMORIM MRS, DANTAS VFS. Potencial energético da biomassa e carvão vegetal do epicarpo e torta de pinhão manso (Jatrophacurcas). Cerne, 2011:17(2): 267-273.

VALLE MLA, SILVA JC, LUCIA RMD, EVANGELISTA WV. Retenção e penetração de CCA em madeira de primeira e segunda rotação de Eucalyptus urophylla S.T. Blake. Sci. For., 2013:23(2): 481-490.

XAVIER A, SILVA RL. Evolução da silvicultura clonal de Eucalyptus no Brasil. Agron. Costarric., 2010:34(1): 93-98. 